\title{
FAKTOR-FAKTOR YANG MEMPENGARUHI DIVIDEND PAYOUT RATIO PADA PERUSAHAAN ASURANSI YANG TERDAFTAR DI BEI PERIODE 2009. 2014
}

\author{
Nani Mulyani \\ Dosen Fakultas Akutansi Universitas Pamulang \\ Email : dosen01981@unpam.ac.id
}

\begin{abstract}
ABSTRAK
Tujuan dari penelitian ini adalah untuk mengetahui factor apa saja yanga mempengaruhi dividend payout ratio pada perusahaan asuransi yamg terdaftar. Dalam penelitian ini menggunakan metode penelitian secara kausalitas yaitu penelitian untuk menguji pengaruh antara variabel independen terhadap variabel dependen.. Hasilnya adalah sudah baik. Hal ini dapat diketahui bahwa dalam berdasarkan $F_{\text {tabel }}$ dengan $\mathrm{df}=$ 6,35 (40) dengan $\alpha=5 \%$ diperoleh nilai $F_{\text {tabel }}$ sebesar 2.34. Maka dapat disimpulkan $\mathrm{F}_{\text {hitung }}(11.81839)>\mathrm{F}_{\text {tabel }}(2.34)$, yang artinya menolak $\mathrm{H}_{0}$ dan menerima $\mathrm{H}_{1}$. Artinya variabel bebas yang terdiri dari adalah Net Income (NI), Earning Growth (Growth), Firm Size (Size), Return On Assets (ROA), Debt to Equity Ratio (DER), Growth Sales $(S G)$ secara bersama-sama memiliki hubungan yang signifikan terhadap variabel terikatnya yaitu Dividend Payout Ratio (DPR)..
\end{abstract}

\section{Kata Kunci : Dividend Payout Ratio, Asuransi, BEI}

\begin{abstract}
The purpose of this study is to find out what factors influence the dividend payout ratio of registered insurance companies. In this study using a causality research method, namely research to test the effect of the independent variables on the dependent variable. The result is good. It can be seen that based on Ftable with $\mathrm{df}=6.35$ (40) with $\alpha=5 \%$, the Ftable value of 2.34 is obtained. Then it can be concluded Fcount (11.81839)> Ftable (2.34), which means rejecting $\mathrm{H} 0$ and accepting $\mathrm{H} 1$. This means that the independent variables consisting of Net Income (NI), Earning Growth (Growth), Firm Size (Size), Return On Assets (ROA), Debt to Equity Ratio (DER), Growth Sales (SG) together have a significant relationship to the dependent variable namely Dividend Payout Ratio (DPR).
\end{abstract}

Keywords: Dividend Payout Ratio, Insurance, IDX 


\section{PENDAHULUAN}

\section{A. Latar Belakang}

Pasar modal merupakan salah satu alternatif pilihan sumber dana jangka panjang bagi perusahaan, termasuk didalamnya adalah perusahaan-perusahaan pada sektor asuransi.Perkembangan perusahaan asuransi di Indonesia sejak awal tahun 1990an menunjukkan hal yang menggembirakan.Pada tahun yang bersamaan telah keluar produk pengaturan perundang-undangan dibidang usaha asuransi yang telah menetapkan berbagai peraturan dan persyaratan baik dalam ijin usaha,permodalan,keahlian,profesionalisas i perusahaan melalui spesialisasi usaha,pembinaansertapengawasan.Menuru t Husnan (2002) investor mempunyai tujuan utama dalam menanamkan dananya kedalam perusahaan asuransi yaitu untuk mencari pendapatan atau tingkat kembalian investasi (return) baik berupa pendapatan dividen maupun pendapatan dari selisih harga jual saham terhadap harga belinya (capital gain). Para investor umumnya menginginkan pembagian dividen yang relatif stabil,karena dengan stabilitas dividen dapat meningkatkan kepercayaan investor terhadap perusahaan sehingga mengurangi ketidakpastian investor dalam menanamkan dananya ke dalam perusahaan. Pembayaran dividenyang semakin besar akan mengurangi tingkat pertumbuhan perusahaan dan selanjutnya akan menurunkan harga saham.Penetapan dividensaham biasa tergantung keputusan rapat umum pemegang saham (RUPS), dimana prosentase pembayaran dividenlebih fleksibel dibandingkan dengan dividenpada saham preferen. Sebagai investor, pemegang saham biasa pasti menginginkan dividenmeningkat dari waktu ke waktu. Perusahaan berusaha memenuhi harapan pemegang saham dan dengan berbagai pertimbangan tersebut pihak manajemen cenderung membatasi pembayaran dividen, dimana keuntungan akan dialokasikan pada laba ditahan (retained Earnings) sebagai sumber dana internal. Bagaimanapun juga pihak manajemen berusaha menghindari terjadinya dividendcut atau paling tidak membayar dividensecara tetap. Menurut Kamus Bank \& Bisnis "pendapatan bersihadalahnet income yaitu selisih positif daritotal pendapatan (operasional dan non-operasional) dengan total biaya (operasional dan non- operasional) dalam 
satu periode setelah dikurangi dengan taksiran pajak pendapatan. Menurut Imam Ghozali (2007) informasi tentang laba juga digunakan untuk efisiensi penggunaan dana yang tertanam dalam perusahaan yang diwujudkan dalam tingkat kembalian, pengukur prestasi manajemen, dasar penentuan besarnya penentuan pengenaan pajak, dasar kompensasi dan pembagian bonus, alat motivasi manajemen dalam pengendalian perusahaan, dasar untuk kenaikan kemakmuran dan juga sebagai dasar deviden.

Menurut Riyanto (2001 : 210), Earnings Growthmerupakan rasio yang mengukur seberapa baik perusahaan mempertahankan posisi ekonominya, baik dalam industrinya maupun dalam kegiatan ekonomi secara keseluruhan. Semakin cepat tingkat pertumbuhan suatu perusahaan, maka semakin besar kebutuhan akan dana untuk membiayai pertumbuhan perusahaan tersebut. Dengan besarnya kebutuhan akan dana untuk waktu mendatang, perusahaan biasanya lebih senang untuk menahan labanya daripada membagikannya sebagai dividen kepada para pemegang saham.
Suatu perusahaan besar yang sudah mapan akan memiliki akses yang mudah menuju pasar modal, sementara perusahaan yang baru dan yang masih kecil akan mengalami banyak kesulitan untuk memiliki akses ke pasar modal. Karena kemudahan akses ke pasar modal cukup berarti untuk fleksibilitas dan kemampuannya untuk memperoleh dana yang lebih besar, sehingga perusahaan mampu memiliki rasio pembayaran dividen yang lebih tinggi daripada perusahaan kecil.

Menurut Susan Irawati (2006:59) menyatakan bahwa Return On Assets(ROA)adalah kemampuan suatu perusahaan (aktiva perusahaan) dengan seluruh modal yang bekerja di dalamnya untuk menghasilkan laba operasi perusahaan (EBIT) atau perbandingan laba usaha dengan modal sendiri dan modal asing yang digunakan untuk menghasilkan laba dan dinyatakan dalam persentase. Return On Assets sering kali disebut sebagai rentabilitas ekonomi (RE) atau Earnings power (IP) .

Menurut Fakhruddin dan Hadianto (2001:61), DebtTo Equity Ratio (DER) yang merupakan rasio utang yang diukur dari perbandingan utang dan ekuitas (modal sendiri). Semakin tinggi debt to equityratio 
(DER) berarti modal sendiri semakin sedikit dibanding hutangnya. Semakin kecil debt to equityratio (DER) semakin baik bagi perusahaan dan akan meningkatkan harga saham. Hal ini akan mengurangi hak pemegang saham (dalam bentuk dividen)

Menurut Kesuma (2009), pertumbuhan penjualan (growth of sales) adalah kenaikan jumlah penjualan dari tahun ke tahun atau dari waktu ke waktu. Perusahaan yang memiliki tingkat pertumbuhan penjualan yang tinggi akan membutuhkan lebih banyak investasi pada berbagai elemen asset, baik asset tetap maupun asset lancar. Dari uraian tersebut diatas maka penelitian ini mencoba untuk mengetahui bagaimana pengaruh $\mathrm{Net}$ Income (NI), Earnings Growth (Growth), Firm Size (Size), Return On Assets (ROA), Debt to Equity Ratio (DER), Growth Sales (SG)terhadap Dividend Payout Ratio(DPR)pada perusahaan-perusahaan asuransi yang terdaftar di Bursa Efek Indonesia (BEI) pada periode 2009 sd 2014

\section{B. Perumusan Masalah}

Berdasar pada latarbelakang tersebut, maka dapat dirumuskan beberapa masalah yang antara lain :
1. Apakah Net Income berpengaruh terhadap Dividend Payout Ratio?

2. Apakah Earnings Growth (Growth)berpengaruh terhadap Dividend Payout Ratio?

3. Apakah FirmSize(Size)berpengaruh terhadap Dividend Payout Ratio?

4. Apakah Return On Assets (ROA)berpengaruh terhadap Dividend Payout Ratio?

5. Apakah Debt to Equity Ratio (DER)berpengaruh terhadap Dividend Payout Ratio?

6. Apakah Growth Sales ( $S G)$ berpengaruh terhadap Dividend Payout Ratio?

7. Apakah Net Income (NI), Earnings Growth (Growth), Firm Size (Size), Return On Assets (ROA), Debt to Equity Ratio (DER), Growth Sales $(S G)$ secara bersama-sama berpengaruh terhadap Dividend Payout Ratio?

\section{Tujuan Penelitian}

Berdasarkan rumusan masalah diatas, maka tujuan dari penelitian ini adalah:

1. Untuk mendapatkan bukti empiris mengenai pengaruh Net Income terhadap Dividend Payout Ratio. 
2. Untuk mendapatkan bukti empiris mengenai pengaruh Earnings Growth (Growth ) terhadap Dividend Payout Ratio.

3. Untuk mendapatkan bukti empiris mengenai pengaruh Firm Size (Size)terhadap Dividend Payout Ratio.

4. Untuk mendapatkan bukti empiris mengenai pengaruh Return On Assets (ROA)terhadap Dividend Payout Ratio.

5. Untuk mendapatkan bukti empiris mengenai pengaruh Debt to Equity Ratio (DER) terhadap Dividend Payout Ratio.

6. Untuk mendapatkan bukti empiris mengenai pengaruh Growth Sales (SG) terhadap Dividend Payout Ratio.

7. Untuk mendapatkan bukti empiris mengenai pengaruh Net Income (NI), Earnings Growth (Growth), Firm Size (Size), Return On Assets (ROA), Debt to Equity Ratio (DER), Growth Sales (SG )secara bersama-sama berpengaruh terhadap Dividend Payout Ratio (DPR).

\section{A. Definisi ASURANSI}

Menurut Abbas Salim (2007:1) mendefinisikan asuransi adalah sebagai berikut:"Asuransi ialah suatu kemauan untuk menetapkan kerugian-kerugian kecil (sedikit) yang sudah pasti sebagai pengganti/substitusi kerugian-kerugian besar yang belum terjadi”.

Asuransi adalah institusi ekonomi yang mengurangi resiko dengan menggabungkan di bawah satu manajemen dan kelompok objek dalam suatu kondisi sehingga kerugian besar yang terjadi yang diderita oleh suatu kelompok yang tadi dapat diprediksi dalam lingkup yang lebih rinci.

\section{B. Manajemen Keuangan}

Menurut Weston dan Copeland yang diterjemahkan oleh Jaka, W. dan Kirbrandoko(2002),“ManajemenKeuangan dapat dirumuskan oleh fungsi dan tanggung jawab para manajer keuangan. Fungsi pokok manajemen keuangan antara lain menyangkut keputusan tentang penanaman modal, pembiayaan kegiatan usaha dan pembagian dividendpada suatu perusahaan."

\section{Dividen}

\section{TINJAUAN PUSTAKA}


Menurut Ross, Westerfield dan Jordan (2008:591), dividend merupakan bagian dari laba perusahaan yang dibayarkan kepada pemegang saham, yang biasanya dibagikan dalam bentuk kas, yang disebut dividend tunai (cash dividend). Jika dibagikan berasal dari sumber lain, selain dari retained earning, hal ini disebut sebagai distribution Besarnya dividend yang dibagikan perusahaan ditentukan oleh para shareholders pada saat berlangsungnya rapat umum pemegang saham (RUPS). Dividend merupakan hak setiap shareholders atas kekayaan yang telah mereka investasikan di suatu perusahaan.

\section{Metode Pembayaran Cash Dividend}

Keputusan memberikan atau tidak memberikan cash dividend terletak pada direksi perusahaan, tetapi setelah diumumkan akan diberikannya sejumlah cash dividend, keputusan tersebut menjadi kewajiban direksi dilaksanakan.

\section{Kebijakan Dividend}

Menurut Margaretha Farah (2014:327) "keputusan tentang laba yang diperoleh akan dibagikan kepada pemegang saham sebagai dividen atau akan ditahan sebagai laba ditahan guna pembiayaan investasi di masa yang akan dating”.Dengan demikian, kebijakan dividen harus dianalisis dalam kaitan dengan keputusan pembelanjaan atau penentu struktur modal keseluruhan yang dapat dijelaskan dengan model sebagai berikut :

$$
P o=\frac{D i}{K s-g}
$$

Model harga saham di atas menunjukkan bahwa pembayaran dividen yang lebih besar $\left(D_{\mathrm{i}}\right)$ cenderung akan meningkatkan harga saham $\left(\mathrm{P}_{\mathrm{o}}\right)$. Meningkatnya harga saham berarti meningkatnya nilai perusahaan. Namun pembayaran dividen yang semakin besar akan mengurangi kemampuan perusahaan untuk investasi sehingga akan menurunkan tingkat pertumbuhan perusahaan (g) dan selanjutnya akan menurunkan harga saham. Jadi, perubahan besarnya dividen akan mengandung 2 (dua) akibat yang saling bertentangan.

Kebijakan dividen yang optimal (optimal dividend policy) adalah kebijakan yang menciptakan keseimbangan antara dividen saat ini dan pertumbuhan di masa datang sehingga memaksimalkan harga saham. Menurut Margaretha Farah (2014:328)

\section{Faktor-Faktor Pembayaran Dividen}


Faktor-Faktor yang mempengaruhi rasio pembayaran Dividendsuatu perusahaan adalah sebagai berikut (Riyanto, 2001) :
a. Posisi Likuiditas Perusahaan
b. Kebutuhan Untuk Membayar Hutang
c. Tingkat Pertumbuhan Perusahaan
d. Pengawasan TerhadapPerusahaan

\section{Kerangka Pemikiran}

Mengacu pada beberapa penelitian mengenai dividen yang telah dilakukan peneliti sebelumnya, maka variabel penelitian ini terdiri dari dua variabel yaitu variabel dependen dan variabel independen. Variabel dependen berupa Dividend Payout Ratio(DPR). Variabel independen dalam penelitian ini berupa Net Income (NI), Earnings Growth (Growth), Firm Size (Size), Return On Assets (ROA), Debt to Equity Ratio (DER), Growth Sales (SG)terhadap Dividend Payout Ratio (DPR) sebagai faktor yang mempengaruhi dividen perusahaan.

Berdasarkan landasan teori, tujuan penelitian, dan hasil penelitian sebelumnya serta permasalahan yang telah dikemukakan

\section{METODE PENELITIAN}

Penelitian ini mengacu pada penelitian maka dalam merumuskan hipotesis, yang dilakukan sebelumnya Unzu Marietta disajikan kerangka pemikiran yang \& Djoko Sampurno (2013), Khoirul Hikmah dituangkan dalam model penelitian pada \& Ririn Astuti (2013), Nadjibah (2008), gambar sebagai berikut: Bagus Laksono(2006), Mahira Rafique 
(2012) dan Harjono (2012). Metode penelitian yang digunakan adalah metode penelitian secara kausalitas yaitu penelitian untuk menguji pengaruh antara variabel independen terhadap variabel dependen. Penulis memilih metode ini karena penulis ingin melihat seberapa besar pengaruh variabel independen yaituNet Income (NI), Earnings Growth (Growth), Firm Size (Size), Return On Assets (ROA), Debt to Equity Ratio (DER), Growth Sales $(S G)$ terhadap variabel dependen yaitu Dividend Payout Ratio(DPR).

\section{Populasi Dan Sample}

Populasi dalam penelitian ini adalah perusahaan asuransi yang terdaftar di Bursa Efek Indonesia selama periode 2009 sampai 2014. Teknik pengambilan Sampel dilakukan dengan Purposive Sampling, dengan kriteria pemilihan seperti Perusahaan telah terdaftar dari tahun 2009 dan masih terdaftar hingga tahun 2014, Perusahaan yang memiliki laporan keuangan lengkap, telah memberikannya ke bursa setiap tahun (dari tahun 2009 sampai dengan 2014), dan data-data yang dibutuhkan untuk variabel penelitian untuk masing-masing perusahaan tersedia lengkap.
Tabel 3.1

\section{Daftar Perusahaan Asuransi yang terdaftar Dibursa Efek Indonesia}

Periode 2009-2013

\begin{tabular}{|c|l|c|}
\hline NO & \multicolumn{1}{|c|}{$\begin{array}{c}\text { NAMA } \\
\text { PERUSAHAAN }\end{array}$} & KODE \\
\hline 1 & $\begin{array}{l}\text { Asuransi Bina Dana } \\
\text { Arta Tbk }\end{array}$ & ABDA \\
\hline 2 & $\begin{array}{l}\text { Asuransi Harta Aman } \\
\text { Pratama Tbk }\end{array}$ & AHAP \\
\hline 3 & $\begin{array}{l}\text { Asuransi Dayin Mitra } \\
\text { Tbk }\end{array}$ & ASDM \\
\hline 4 & $\begin{array}{l}\text { Asuransi Jaya Tania } \\
\text { Tbk }\end{array}$ & ASJT \\
\hline 5 & $\begin{array}{l}\text { Asuransi Ramayana } \\
\text { Tbk }\end{array}$ & ASRM \\
\hline 6 & $\begin{array}{l}\text { Lippo General } \\
\text { Insurance Tbk }\end{array}$ & LPGI \\
\hline 7 & $\begin{array}{l}\text { Maskapai Reasuransi } \\
\text { Indonesia Tbk }\end{array}$ & MREI \\
\hline
\end{tabular}

Dalam penelitian ini, menggunakan data sekunder, berupa laporan keuangan. Dengan demikian langkah yang dilakukan adalah dengan mencatat seluruh data yang diperlukan dalam penelitian ini selama periode 2009-2014 dimana data Net Income (NI), Earnings Growth (Growth), Firm Size (Size), Return On Assets (ROA), Debt to 
Equity Ratio (DER), Growth Sales (SG)terhadap Dividend Payout Ratio (DPR) danDividend Payout Ratio(DPR) diperoleh Indonesia Stock Exchange (IDX) dan laporan keuangan perusahaan yang terdapat di Bursa Efek Indonesia (BEI).

\section{HASIL DAN PEMBAHASAN}

\section{A. Analisis Deskriptif Statistik}

Statistik deskriptif digunakan untuk melihat gambaran umum dari data yang digunakan. Dimana hasil statistik deskriptif dibawah ini akan memberikan gambaran umum terhadap objek penelitian yang dijadikan sampel penelitian Effectiveness (Efektivitas).

Dimana statistik deskripif lebih difokuskan kepada nilai tertinggi, nilai terendah, rata-rata dan standar deviasi dari setiap variabel yang diteliti yang berjumlah 7 (tujuh) Perusahaan Asuransi pada tahun 2010 sampai 2014, baik itu variabel bebas yang terdiri dari Net Income (NI), Earning Growth (Growth), Firm Size (Size), Return On Assets (ROA), Debt to Equity Ratio (DER), Growth Sales (SG) dan, serta variabel terikatnya yaitu Dividend Payout Ratio (DPR)..
Berdasarkan Tabel 4.1 diatas dapat disimpulkan bahwa :

1. Rata-rata rasio Dividend Payout Ratio (DPR) selama periode pengamatan 2009 sampai dengan 2014 adalah 0.260257. Rasio Dividend Payout Ratio (DPR) tertinggi yaitu sebesar 1.078457 dan nilai Dividend Payout Ratio (DPR) terendah yaitu 0.055358 . Dimana nilai standar deviasi dari variabel dividend payout ratio (DPR) adalah sebesar 0.173473 .

2. Rata-rata rasio Net Income (NI) selama periode pengamatan 2009 sampai dengan 2014 adalah 17.43826. Rasio Net Income (NI) tertinggi yaitu sebesar 18.96441 dan nilai Net Income (NI) terendah yaitu 15.05853. Dimana nilai standar deviasi dari variabel $\mathrm{Net}$ Income (NI) adalah sebesar 0.922453.

3. Rata-rata Earnings Growth (Growth) selama periode pengamatan 2009 sampai dengan 2014 adalah 0.409286. Rasio Earnings Growth (Growth) tertinggi yaitu sebesar 2.050000 dan nilai Earnings Growth (Growth) terendah yaitu -0.550000. Dimana nilai standar deviasinya adalah sebesar 0.532135 . 
4. Rata-rata rasio Firm Size (Size) selama periode pengamatan 2009 sampai dengan 2014 adalah 20.19728. Rasio Firm Size (Size) tertinggi yaitu sebesar 21.70947 dan nilai Firm Size (Size) terendah yaitu 18.42835. Dimana nilai standar deviasi dari variabel Firm Size (Size) adalah sebesar 0.885879 .

5. Rata-rata rasio Return On Assets (ROA) selama periode pengamatan 2009 sampai dengan 2014 adalah 0.062082. Rasio Return On Assets (ROA) tertinggi yaitu sebesar 0.214469 dan nilai Return On Assets (ROA) terendah yaitu 0.017151 . Dimana nilai standar deviasi dari variabel Return On Assets (ROA) adalah sebesar 0.034352 .

6. Rata-rata Debt To Equity Ratio (DER) selama periode pengamatan 2009 sampai dengan 2014 adalah 2.247300. Rasio Debt To Equity Ratio (DER) tertinggi yaitu sebesar 5.671881 dan nilai Debt To Equity Ratio (DER) terendah yaitu 0.274529. Dimana nilai standar deviasinya adalah sebesar 1.620745 .

7. Rata-rata Growth Sales (Sales) selama periode pengamatan 2009 sampai dengan 2014 adalah 0.229692. Rasio Growth Sales (Sales) tertinggi yaitu sebesar 0.547480 dan nilai Growth Sales (Sales) terendah yaitu 0.130800. Dimana nilai standar deviasinya adalah sebesar 0.161873 .

Model Regresi yang disusun dalam penelitian ini adalah :

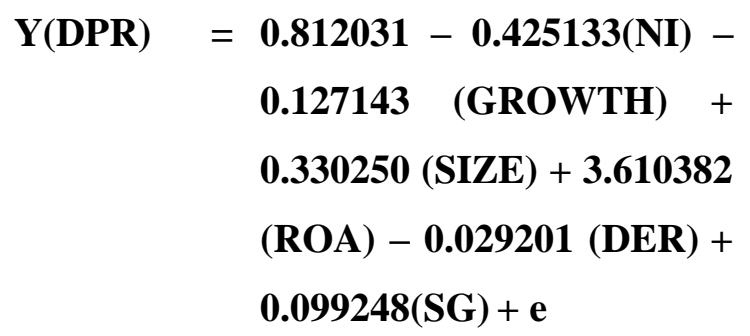

Persamaan regresi diatas memiliki makna:

1. Nilai konstanta sebesar 0.812031 menggambarkan bahwa apabila Net Income (NI), Earning Growth (Growth), Firm Size (Size), Return On Assets (ROA), Debt to Equity Ratio (DER), Growth Sales (SG) mempengaruhi secara konstan terhadap Dividend Payout Ratio (DPR) maka Dividend Payout Ratio (DPR) akan tetap bernilai sebesar 0.812031 poin.

2. Hasil perhitungan dari variabel Net Income (NI) terlihat mempunyai korelasi negatif terhadap Dividend 
Payout Ratio (DPR). Naiknya nilai Net Income (NI) akan mendorong turunnya Dividend Payout Ratio (DPR). Begitu pula sebaliknya, apabila nilai Net Income (NI) mengalami penurunan, maka akan mendorong naiknya Dividend Payout Ratio (DPR). Hal ini tampak jelas pada hasil analisa regresi dimana variabel Net Income (NI) sebesar 0.425133, menandakan adanya korelasi negatif terhadap Dividend Payout Ratio (DPR), artinya apabila nilai Net Income (NI) naik sebesar 1 poin, maka nilai Dividend Payout Ratio (DPR) akan mengalami penurunan sebesar 0.425133 poin. Demikian pula sebaliknya, apabila nilai Net Income (NI) turun sebesar 1 poin maka Dividend Payout Ratio (DPR) akan mengalami kenaikan sebesar 0.425133 poin.

2. Hasil perhitungan dari variabel Earning Growth (Growth)terlihat mempunyai korelasi negatif terhadap Dividend Payout Ratio (DPR). Naiknya nilai Earning Growth (Growth) akan mendorong turunnya Dividend
Payout Ratio (DPR). Begitu pula sebaliknya, apabila nilai Earning Growth (Growth) mengalami penurunan, maka akan mendorong naiknya Dividend Payout Ratio (DPR). Hal ini tampak jelas pada hasil analisa regresi dimana variabel Earning Growth (Growth) sebesar $\quad-0.127143$, menandakan adanya korelasi negatif terhadap Dividend Payout Ratio (DPR), artinya apabila nilai Earning Growth (Growth) naik sebesar 1 poin, maka nilai Dividend Payout Ratio (DPR) akan mengalami penurunan sebesar 0.127143 poin. Demikian pula sebaliknya, apabila nilai Earning Growth (Growth) turun sebesar 1 poin maka Dividend Payout Ratio (DPR) akan mengalami kenaikan sebesar 0.127143 poin.

4. Hasil perhitungan variabel Firm Size (Size)terlihat memiliki korelasi yang positif terhadap Dividend Payout Ratio (DPR). Bila nilai Firm Size (Size) naik maka Dividend Payout Ratio (DPR) akan mengalami 
kenaikan. Begitu pula sebaliknya apabila nilai Firm Size (Size) turun maka akan mendorong pula menurunnya nilai Dividend Payout Ratio (DPR). Hal ini tampak jelas pada hasil analisa regresi dimana variabel Firm Size (Size) sebesar 0.330250, menandakan adanya korelasi positif Firm Size (Size) terhadap Dividend Payout Ratio (DPR), artinya apabila nilai Firm Size (Size) meningkat 1 poin, maka Dividend Payout Ratio (DPR) juga akan mengalami kenaikan sebesar 0.330250 poin. Begitupun sebaliknya, apabila nilai Firm Size (Size) mengalami penurunan sebesar 1 poin maka nilai Dividend Payout Ratio (DPR) juga akan mengalami penurunan sebesar 0.330250 poin.

5. Hasil perhitungan variabel Return On Assets (ROA) terlihat memiliki korelasi yang positif terhadap Dividend Payout Ratio (DPR). Bila nilai Return On Assets (ROA) naik maka Dividend Payout Ratio (DPR) akan mengalami kenaikan. Begitu pula sebaliknya apabila nilai Return On Assets (ROA) turun maka akan mendorong pula menurunnya nilai Dividend Payout Ratio (DPR).

6. Hasil perhitungan variabel Debt to Equity Ratio (DER) terlihat memiliki korelasi yang negatif terhadap Dividend Payout Ratio (DPR). Bila nilai Debt to Equity Ratio (DER) naik maka Dividend Payout Ratio (DPR) akan mengalami penurunan. Begitu pula sebaliknya apabila nilai Debt to Equity Ratio (DER) turun maka akan mendorong naiknya nilai Dividend Payout Ratio (DPR).

7. Untuk perhitungan variabel Growth Sales $(S G)$ terlihat memiliki korelasi yang positif terhadap Dividend Payout Ratio (DPR). Bila nilai Growth Sales (SG) naik maka Dividend Payout Ratio (DPR) akan mengalami kenaikan. Begitu pula sebaliknya apabila nilai Growth Sales (SG) turun maka akan mendorong pula menurunnya nilai Dividend Payout Ratio (DPR). 
Dependent Variable: DPR

Method: Least Squares

Sample: 142

Included observations: 42

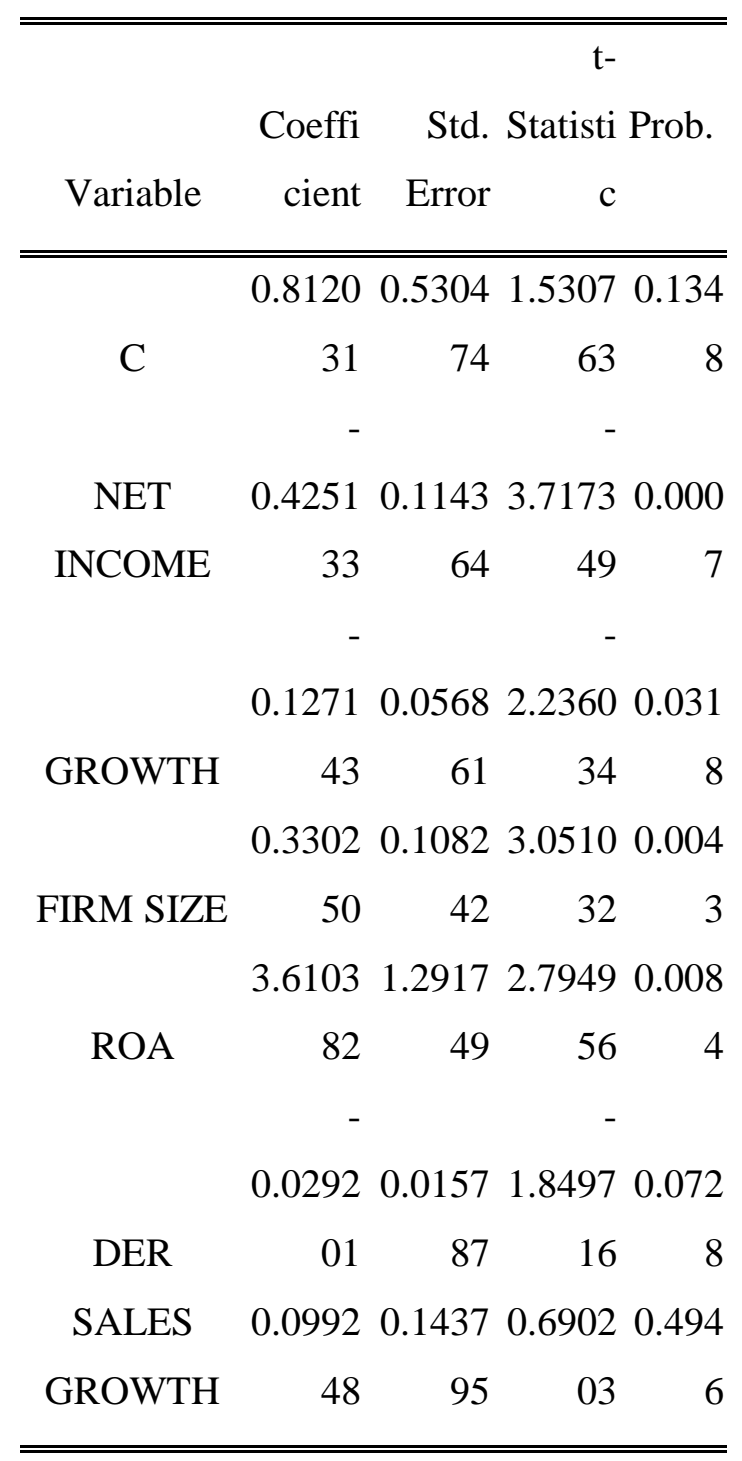

Uji T
Uji hipotesis ini dilakukan untuk mengetahui ada/atau tidaknya pengaruh variabel bebas dengan variabel terikatnya secara parsial. Hasil analisis antara variabel bebas yaitu yang terdiri dari Net Income (NI), Earning Growth (Growth), Firm Size (Size), Return On Assets (ROA), Debt to Equity Ratio (DER), Growth Sales (SG) terhadap variabel terikatnya yaitu Dividend Payout Ratio (DPR). Dengan menggunakan program Eviews 8 diperoleh hasil perhitungan pada tabel 4.15.

Adapun batas toleransi kesalahan $(\infty)$ yang digunakan adalah 5\%. Apabila $\mathrm{p}<\infty$ atau $\mathrm{p}<0,05$ maka terdapat pengaruh yang signifikan antara variabel independen terhadap variabel dependen.

\section{Tabel 4.15}

\section{Hasil Regresi (UJI T)}

Sumber: Data diolah dengan Eviews 8, 2015

1. Dari hasil perhitungan tersebut dapat diketahui bahwa hasil uji $\mathrm{t}$ untuk variabel Net Income (NI) diperoleh $t_{\text {hitung }}$ sebesar -3.717349 dengan probabilitas sebesar 0.0007 .

Dengan menggunakan dasar keputusan seperti diatas, diketahui 
berdasarkan tabel distribusi t dua sisi pada $\mathrm{df}=35$ (40) dengan $\alpha=5 \%$ diperoleh nilai $t_{\text {tabel }}$ sebesar 2.021. Maka dapat disimpulkan $t_{\text {hitung }}$ ($3.717349)>t_{\text {tabel }}(2.021)$, yang artinya menolak $\mathrm{H}_{0}$ dan menerima $\mathrm{H}_{1}$. Sehingga hipotesis pertama yang diajukan menyatakan Net Income (NI) berpengaruh signifikan terhadap Dividend Payout Ratio (DPR) dapat diterima.

2. Dari hasil perhitungan selanjutnya uji $\mathrm{t}$ untuk variabel Earning Growth (Growth) diperoleh $t_{\text {hitung }}$ sebesar 2.236034 dengan probabilitas sebesar 0.0318. Dasar pengambilan keputusan untuk variabel Earning Growth (Growth) sebagai berikut :

Dengan menggunakan dasar keputusan seperti diatas, diketahui berdasarkan tabel distribusi $\mathrm{t}$ dua sisi pada $\mathrm{df}=35$ (40) dengan $\alpha=5 \%$ diperoleh nilai $t_{\text {tabel }}$ sebesar 2.021. Maka dapat disimpulkan $t_{\text {hitung }}$ ($2.236034)>t_{\text {tabel }}(2.021)$, yang artinya menolak $\mathrm{H}_{0}$ dan menerima $\mathrm{H}_{1}$. Sehingga hipotesis kedua yang diajukan menyatakan Earning Growth
(Growth) berpengaruh signifikan terhadap Dividend Payout Ratio (DPR) dapat diterima.

Dengan menggunakan dasar keputusan seperti diatas, diketahui berdasarkan tabel distribusi t dua sisi pada $\mathrm{df}=35$ (40) dengan $\alpha=5 \%$ diperoleh nilai $t_{\text {tabel }}$ sebesar 2.021 . Maka dapat disimpulkan $t_{\text {hitung }}$ (3.051032) > $\mathrm{t}_{\text {tabel }}$ (2.021), yang artinya menolak $\mathrm{H}_{0}$ dan menerima $\mathrm{H}_{1}$. Sehingga hipotesis ketiga yang diajukan menyatakan Firm Size (Size) berpengaruh signifikan terhadap Dividend Payout Ratio (DPR) dapat diterima.

4. Dari hasil perhitungan tersebut dapat diketahui bahwa hasil uji $\mathrm{t}$ untuk variabel Return On Assets (ROA) diperoleh $t_{\text {hitung }}$ sebesar 2.794956 dengan probabilitas sebesar 0.0084 .

Dengan menggunakan dasar keputusan seperti diatas, diketahui berdasarkan tabel distribusi t dua sisi pada df $=35$ (40) dengan $\alpha=5 \%$ diperoleh nilai $t_{\text {tabel }}$ sebesar 2.021. Maka dapat disimpulkan $t_{\text {hitung }}$ (2.794956) > $t_{\text {tabel }}$ (2.021), yang 
artinya menolak $\mathrm{H}_{0}$ dan menerima $\mathrm{H}_{1}$. Sehingga hipotesis keempat yang diajukan menyatakan Return On Assets (ROA) berpengaruh signifikan terhadap Dividend Payout Ratio (DPR) dapat diterima.

5. Hasil perhitungan selanjutnya uji $\mathrm{t}$ untuk variabel Debt to Earning Ratio (DER) diperoleh $t_{\text {hitung }}$ sebesar 1.849716 dengan probabilitas sebesar 0.0728 .

Dengan menggunakan dasar keputusan seperti diatas, diketahui berdasarkan tabel distribusi t dua sisi pada df $=35$ (40) dengan $\alpha=5 \%$ diperoleh nilai $\mathrm{t}_{\text {tabel }}$ sebesar 2.021. Maka dapat disimpulkan $t_{\text {hitung }}$ ($1.849716)<\mathrm{t}_{\text {tabel }}(2.021)$, yang artinya gagal menolak $\mathrm{H}_{0}$. Sehingga hipotesis kelima yang diajukan menyatakan Debt to Earning Ratio (DER) berpengaruh signifikan terhadap Dividend Payout Ratio (DPR) tidak dapat diterima.

6. Hasil perhitungan selanjutnya uji $\mathrm{t}$ untuk variabel Growth Sales (SG) diperoleh $t_{\text {hitung }}$ sebesar 0.690203 dengan probabilitas sebesar 0.4946 .

\section{Koefisien Determinasi}

Koefisien Determinasi $\left(\mathrm{R}^{2}\right)$ pada intinya adalah untuk mengukur seberapa jauh kemampuan model dalam menerangkan variabel dependennya (Nathaniel, 2008). Hasil perhitungan Koefisien Determinasi $\left(\mathrm{R}^{2}\right)$ dari penelitian ini dapat dilihat pada tabel 4.16. sebelumnya dengan menggunakan program Eviews 8

\section{Tabel 4.16}

\section{Hasil Regresi $\left(\mathbf{R}^{2}\right)$}

\begin{tabular}{ll}
\hline \hline R-squared & 0.669532 \\
Adjusted R-squared & 0.612880 \\
S.E. of regression & 0.107933 \\
Sum squared resid & 0.407733 \\
Log likelihood & 37.73566 \\
F-statistic & 11.81839 \\
Prob(F-statistic) & 0.000000 \\
\hline
\end{tabular}

Sumber : Data diolah dengan Eviews 8, 2015

Dari hasil perhitungan koefisien determinasi (Adjusted R-Square) adalah sebesar 0.612880 atau sebesar $61.3 \%$. Hal ini menunjukan bahwa variabel-variabel $\mathrm{Net}$ Income (NI), Earning Growth (Growth), 
Firm Size (Size), Return On Assets (ROA), Debt to Equity Ratio (DER), Growth Sales (SG) mampu menjelaskan variasi naik/turunnya Dividend Payout Ratio (DPR) sebesar $61.3 \%$ sedangkan sisanya sebesar $38.7 \%$ dijelaskan oleh variabel-variabel lain yang tidak dimasukan dalam model regresi ini

\section{Uji F}

Uji F-testini digunakan untuk mengetahui pengaruh variabel bebas dalam hal ini adalah Net Income (NI), Earning Growth (Growth), Firm Size (Size), Return On Assets (ROA), Debt to Equity Ratio (DER), Growth Sales (SG) secara bersamasama terhadap variabel terikatnya yaitu Dividend Payout Ratio (DPR). Dengan menggunakan program Eviews 8 diperoleh hasil perhitungan pada tabel 4.17

Tabel 4.17

\section{Hasil Regresi (UJI F)}

\begin{tabular}{ll}
\hline \hline R-squared & 0.669532 \\
Adjusted R-squared & 0.612880 \\
S.E. of regression & 0.107933 \\
Sum squared resid & 0.407733 \\
Log likelihood & 37.73566 \\
F-statistic & 11.81839
\end{tabular}

$$
\text { Prob(F-statistic) } \quad 0.000000
$$

Sumber : Data diolah dengan Eviews 8,

$$
2015
$$

Dari hasil perhitungan tersebut, dapat diketahui bahwa hasil uji $F_{\text {hitung }}$ sebesar 11.81839 dengan probabilitas sebesar 0.000000 .

Dengan menggunakan dasar keputusan seperti diatas, diketahui berdasarkan $\mathrm{F}_{\text {tabel }}$ dengan $\mathrm{df}=6,35$ (40) dengan $\alpha=5 \%$ diperoleh nilai $\mathrm{F}_{\text {tabel }}$ sebesar 2.34. Maka dapat disimpulkan $F_{\text {hitung }}$ (11.81839) > $F_{\text {tabel }}$ (2.34), yang artinya menolak $\mathrm{H}_{0}$ dan menerima $\mathrm{H}_{1}$. Artinya variabel bebas yang terdiri dari adalah $\mathrm{Net}$ Income (NI), Earning Growth (Growth), Firm Size (Size), Return On Assets (ROA), Debt to Equity Ratio (DER), Growth Sales $(S G)$ secara bersama-sama memiliki hubungan yang signifikan terhadap variabel terikatnya yaitu Dividend Payout Ratio (DPR).

\section{KESIMPULAN DAN SARAN}

\section{A. KESIMPULAN}

Tujuan dari penelitian ini adalah untuk menguji dan menganalisis pengaruh Net Income (NI), Return On Assets (ROA), Firm 
Size, Earnings Growth, Sales dan Debt to Equity Ratio (DER) terhadap Dividend Payout Ratio (DPR) perusahaan Asuransi yang tercatat Di Bursa Efek Indonesia selama periode tahun 2009 sampai dengan tahun 2014. Berdasarkan hasil yang telah dikemukakan pada bab sebelumnya, maka dapat diperoleh kesimpulan sebagai berikut :

1. Variabel Net Income (NI) secara parsial memiliki korelasi yang negatif dan signifikan terhadap Dividend Payout Ratio (DPR) perusahaan Asuransi yang tercatat Di Bursa Efek Indonesia selama periode tahun 2009 sampai dengan tahun 2014. Hasil penelitian ini sesuai dengan penelitian yang dilakukan oleh Muhammad Ridha Ramli \& Muhammad Arfan (2011) yang menyatakan bahwa Net Income (NI) memiliki pengaruh negatif dan signifikan terhadap Dividend Payout Ratio (DPR).

2. Variabel Return On Assets (ROA) secara parsial mempunyai korelasi yang positif dan signifikan terhadap Dividend Payout Ratio (DPR) perusahaan Asuransi yang tercatat Di Bursa Efek Indonesia selama periode tahun 2009 sampai dengan tahun
2014. Hasil penelitian ini sesuai dengan penelitian yang dilakukan oleh Nadjibah (2008) dan Bagus Laksono (2006) yang menyatakan bahwa variabel Return On Assets (ROA) memiliki pengaruh positif dan signifikan terhadap Dividend Payout Ratio (DPR).

3. Variabel Firm Size secara parsial mempunyai korelasi yang positif dan signifikan terhadap Dividend Payout Ratio (DPR) perusahaan Asuransi yang tercatat Di Bursa Efek Indonesia selama periode tahun 2009 sampai dengan tahun 2014. Hasil penelitian ini sesuai dengan penelitian yang dilakukan oleh Unzu Marietta \& Djoko Sampurno (2013) yang menyatakan bahwa variabel Firm Size memiliki pengaruh positif dan signifikan terhadap Dividend Payout Ratio (DPR).

4. Variabel Earnings Growth secara parsial mempunyai korelasi yang negatif dan signifikan terhadap Dividend Payout Ratio (DPR) perusahaan Asuransi yang tercatat Di Bursa Efek Indonesia selama periode tahun 2009 sampai dengan tahun 
2014. Hasil penelitian ini tidak sesuai dengan penelitian yang dilakukan oleh Unzu Marietta \& Djoko Sampurno (2013) yang menyatakan bahwa variabel Growth negatif dan tidak signifikan sedangkan penelitian saya di dapat variabel Growth memiliki pengaruh negatif dan signifikan terhadap Dividend Payout Ratio (DPR).

5. Variabel Growth Sales secara parsial mempunyai korelasi yang positif dan signifikan terhadap Dividend Payout Ratio (DPR) perusahaan Asuransi yang tercatat Di Bursa Efek Indonesia selama periode tahun 2009 sampai dengan tahun 2014 Hasil penelitian ini sesuai dengan penelitian yang dilakukan oleh Khoirul Hikmah \& Ririn Astuti (2013) yang menyatakan bahwa variabel Growth Sales memiliki pengaruh positif dan signifikan terhadap Dividend Payout Ratio (DPR).

6. Variabel Debt to Equity Ratio (DER) secara parsial mempunyai korelasi yang positif dan signifikan terhadap Dividend Payout Ratio (DPR) perusahaan Asuransi yang tercatat Di
Bursa Efek Indonesia selama periode tahun 2009 sampai dengan tahun 2014. Hasil penelitian ini sesuai dengan penelitian yang dilakukan oleh Unzu Marietta \& Djoko Sampurno (2013) yang menyatakan bahwa variabel Debt to Equity Ratio (DER) memiliki pengaruh positif dan signifikan terhadap Dividend Payout Ratio (DPR).

7. Variabel independen yang terdiri dari Net Income (NI), Earnings Growth (Growth), Firm Size (Size), Return On Assets (ROA), Debt to Equity Ratio (DER), Growth Sales (SG) secara bersama-sama memiliki pengaruh signifikan terhadap Dividend Payout Ratio (DPR) perusahaan Asuransi yang tercatat Di Bursa Efek Indonesia selama periode tahun 2009 sampai dengan tahun 2014. Hal ini ditunjukan dengan nilai F-test, dimana $F_{\text {hitung }}$ (22.53884) > $\mathrm{F}_{\text {tabel }}(2.34)$.

\section{B. SARAN}

1. Penelitan ini masih terdapat beberapa banyak kekurangan seperti misalnya obyek pengamatan hanya pada perusahaan Asuransi yang 
terdaftar di Bursa Efek

Indonesia, dengan periode

penelitian hanya selama tahun 2009 sampai dengan tahun 2014. Dimana variabel independen penelitian ini hanya menggunakan dari Net Income (NI), Earnings Growth (Growth), Firm Size (Size), Return On Assets (ROA), Debt to Equity Ratio (DER), Growth Sales $(S G)$.

2. Oleh sebab itu disarankan pada penelitian selanjutnya agar menambah periode pengamatan untuk penelitian yang digunakan sehingga menghasilkan informasi yang lebih mendukung, menambah jumlah sampel yang digunakan dan diperluas ke beberapa sektor perusahaan, serta memperbanyak variabel independen yang digunakan dan mempertimbangkan pula faktorfaktor lain yang mempengaruhi Dividend Payout Ratio (DPR) seperti rasio profitabilitas, rasio solvabilitas selain DER, rasio likuiditas dan sebagainya sehingga akan memberikan informasi yang lebih baik dan akurat untuk penelitian di masa mendatang.

\section{DAFTAR PUSTAKA}

Adhista, Setyarini. (2009). Analisis Pengaruh CAR, NIM, BOPO, LDR, GWM Terhadap Perubahan Laba (Studi Pada Bank Pembangunan Daerah Di Indonesia Periode 2005-2007). Program Studi Magister Manajemen UNDIP Semarang. (Telah Dipublikasikan)

Bank Indonesia. (2005-2014). Laporan Data Inflasi dan Informasi Kurs, www.bi.go.id.

Bursa Efek Indonesia. (2005-2014). Laporan Keuangan dan Tahunan, www.idx.co.id.

Djohanputro, Bramantyo. (2008). Manajemen Risiko Korporat. Jakarta: PPM.

Dwijayanthy, Febrina dan Prima Naomi. (2009). Analisis Pengaruh Inflasi, BI Rate, dan Nilai Tukar Mata Uang terhadap Profitabilitas Bank Periode 2003-2007. Universitas Paramadina Jakarta. Jurnal Karisma, Vol. 3 (2), Hal 87-98, 2009.

Esti, Hedwigis dan Dwiningtyas Anggraeni. (2013). Pengaruh Faktor Internal Dan Eksternal Bank Terhadap 
Profitabilitas Bank Persero. Jurnal Manajemen Institut Perbanas, Vol. 1, Hal 1-17.

Fahmi. (2012). Pengantar Manajemen Keuangan. Penerbit Alfabeta, Bandung.

Ghozali, Imam. (2011). Aplikasi Analisis Multivariate dengan Program SPSS. Edisi 3. Semarang : Badan

Harahap, Sofian Safri. (2010). Analisis Kritis Atas Laporan Keuangan, Jakarta: Rajawali Persada.

Kuncoro, Riduwan. (2011). Dasar-Dasar Statistika. Bandung: Alfabeta.

Loen, B. \& Ericson, S. (2008). Manajemen Aktiva Pasiva Bank Devisa. Jakarta: Grasindo.

Mankiw, Gregory N. (2011). Makroekonomi. Edisi 6, Jakarta: Erlangga.

Ogowewo, T. I. \& Uche, C. (2006). (Mis)using Bank Share Capital as a Regulatory Tool to Force Bank Consolidations in Nigeria. Journal of African Law, 50 (2): 161-186. Diakses di http://papers.ssrn.com/sol3/papers. cfm?abstract_id=1231064.

Oktrima, B. (2017). Pengaruh Profitabilitas, Likuiditas, Dan Struktur Modal Terhadap Nilai Perusahaan. Open Journal. Universitas Pamulang.

Oktrima,B.,\&Riani, N. (2019). PENGARUH PERPUTARAN KAS DAN PERPUTARAN
PIUTANG TERHADAP RETURN ON INVESTMENT (ROI) PADA PT. SEMEN INDONESIA (PERSERO) TBK PERIODE TAHUN 2008-2017. Jurnal Ekonomi Efektif, 2(1).

Oktrima, B. (2018). ANALISIS KINERJA KEUANGAN MENGGUNAKAN RASIO PROFITASBILITAS DAN LIKUIDITAS PADA PT. RAMAYANA LESTARI SENTOSA, TBK. Jurnal Ekonomi Efektif, 1(1).

Peraturan Bank Indonesia No. 6/10/PBI/2004 tanggal 12 April 2004 tentang CAMEL (Capital, Asset, Management, Earning, Liquidity).

Peraturan Bank Indonesia (PBI) Nomor.12/19/PBI/2010 tanggal 4 Oktober 2010 tentang Giro Wajib Minimum Bank Umum Pada Bank Indonesia Dalam Rupiah Dan Valuta Asing.

Peraturan Bank Indonesia Nomor 13/1/PBI/2011 tanggal 5 Januari 2011 tentang Penilaian Tingkat Kesehatan Bank Umum.

Peraturan Bank Indonesia Nomor 14/26/PBI/2012 tanggal 27 Desember 2012 tentang Kegiatan Usaha dan Jaringan Kantor Berdasarkan Modal Inti Bank. 
JRRAL ПMМАH P-ISSN 2615-6849, E-ISSN 2622-3686

Peraturan Bank Indonesia No.15/8/PBI/2013 tanggal 7 Oktober 2013 tentang Transaksi Hedging (Lindung Nilai) Kepada Bank.

Peraturan Bank Indonesia No.15/12/PBI/2013 tanggal 12 Desember 2013 tentang Kewajiban Penyediaan Modal Minimum Bank Umum.

Purnomo, S., \& Pasaribu, V. L. D. (2019). PERGERAKAN HARGA SAHAM PT ADARO ENERGY TBK (ADRO) PADA PENGUMUMAN DIVIDEN
INTERIM TAHUN BUKU 2018. Jurnal Ekonomi Efektif, 2(1).

Weygandt, et al, Jerry J. (2011). Financial Accounting. Jhon Willey \& Sons. New Jersey.

Yuliani. (2007). Hubungan Efisiensi Operasional Dengan Kinerja Profitabilitas Pada Sektor Perbankan Yang Go Publik Di Bursa Efek Jakarta. Jurnal Manajemen \& Bisnis Sriwijaya Vol.5 No 10 Desember 2007. 